\title{
【奨励賞研究】
}

\section{口腔乾燥症診断支援のための 口腔内湿潤環境の評価手法の提案}

\author{
細山田 格之 \\ 大阪電気通信大学大学院 医療福祉工学専攻
}

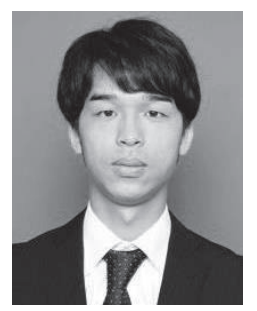

\section{1. はじめに}

口腔乾燥症は唾液分泌量の減少を原因とする疾患であり 1), 撕下 困難や味覚障害等の要因となりうる. その診断方法は唾液分泌量を 調べるために唾液や口に含んだガーゼ等を吐出する行為を伴らもの が多く, 患者に精神的苦痛を与える可能性がある.

本研究では, 唾液の約 $99 \%$ が水であることから ${ }^{2)}$, 唾液分泌量の 推定に口腔内相対湿度を時系列的に計測する手法を用いる. 本論 文では, 口腔内相対湿度の時系列計測システムを構築し, ヒ下の口 腔内湿潤環境を備えた人工口腔内において喠液分泌量の多少によ る違いを調べる. また, 実口腔内での計測を行い唾液分泌量との関 係を見出したので報告する.

\section{2. 口腔内相対湿度時系列計測システムの構築}

本研究では口腔内に相対湿度センサを内蔵したセンサユニットを 挿入する形態を採用する(Fig.1 (a)). 構築したシステムは, 電気抵抗 型相対湿度センサ (TDK 社製, CHS-GSS), ボルテージフォロア, $\mathrm{A} / \mathrm{D}$ 変換器 (サンプリング周波数 $10 \mathrm{~Hz}$, 量子化ビッ坆 12 ビット) 及 び PC より構成されており, 相対湿度セン少の出力信号を PC にて時 系列的に記録する.

\section{1 人エロ腔における計測}

本手法の有効性を確認するため, ヒトの口腔内を模擬した人工口 腔を用いて計測を行った. 概要を Fig.1 (b) に示寸. 人工口腔の容積 は30ml とし, 顎下腺の模擬として底部に接続したシリコンチューブは シリンジポンプに接続されており, 流量を制御可能とした. 通常状態 として $1.0 \mathrm{~m} / \mathrm{min}$, 乾燥状態では $0.1 \mathrm{ml} / \mathrm{min}$ に流量を設定し, 送液寸 る液体は $309.15 \mathrm{~K}\left(36^{\circ} \mathrm{C}\right)$ の温水を使用する. 人工口腔への送液と同 時に記録を開始し 100 秒間計測を行った.

実験結果を Fig. 2 に示す. 送液流量によって出力信号の立ち上が りが異なった為, 計測開始 10 秒間の出力信号から最小二乗法により 傾きを算出し比較を行った. その結果, 通常状態の群と乾燥状態の 群との間に有意な差 $(P<0.05)$ を確認した.

\section{2 実口腔における計測}

構築したシステムを用いて, 健常男性 3 名に対し実口腔での計測 を行った. センサユニットとして相対湿度センサを内蔵したアクリル製 の円筒型容器を作製した. 吐唾法による唾液分泌量計測の後に本シ ステムでの計測を行い，口腔内にセンサユニットを挿入した時点から 60 秒間の出力信号を記録した. 計測中は鼻呼吸を行わせた. 尚, 被 験者へは事前に本実験の趣旨を説明し, 実験に関する同意書への 署名の後に計測を行った. 本研究における実駼は大阪電気通信大 学生体を対象と寸る研究および教育に関する倫理委員会の承認を 得て行われた. (承認番号 15-006 号)
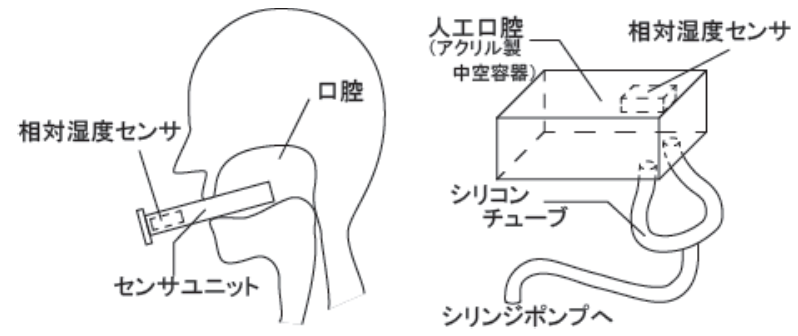

(a) 口腔内相対湿度計測システム の概念図

(b) 人工口腔の概要

Fig.1 本研究における計測手法と人工口腔の概要

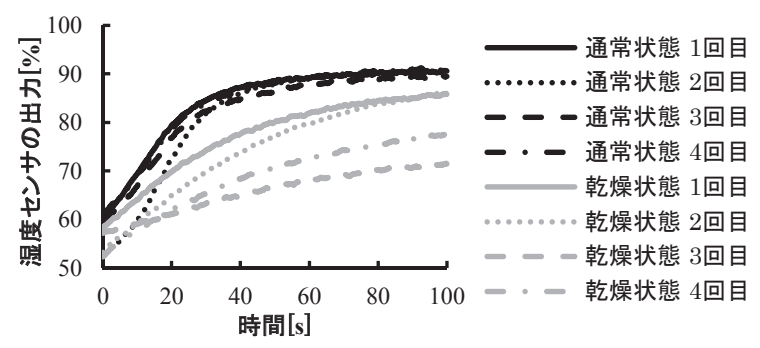

Fig.2 人工口腔内相対湿度の計測結果

実験の結果, 人工口腔と同様の出力信号を認めた為, 人工口腔と 同様に傾きを算出した。 その結果, 吐唾法で求めた唾液分泌量と傾 きとの間に強い相関 $(R>0.8)$ を認めた.

\section{3. まとめ}

口腔乾燥症の診断支援を目指した口腔内相対湿度の時系列計測 システムを構築し，ヒトの口腔内湿潤環境を模擬した人工口腔及び 実口腔において計測を行った. 人工口腔において, 計測開始 10 秒 間の值に対し最小二乗法により傾きを算出した結果, 送液流量の多 少と傾きの間に有意な差が認められた. 実口腔においても, 人工口 腔と同様に傾きを算出し，吐唾法により得た唾液分泌量との関係を 調べた. その結果, 両者の間に強い相関が認められた為, 本手法に おいて唾液分泌量の推定が可能であることが示唆された.

\section{参考文献}

1）池田裕子, 岡本真理子, 山本健, 今村武浩, 山近重生, 斎藤一 郎, 中川洋一: "ドライマウス患者における睡眠の質の評価とその 低下に関連寸る因子", 歯科薬物療法, Vol.33, No.1, pp.1017(2014)

2）張剛太, 中江良子, 石川康子: "口腔乾燥症の発症機序とアクア ポリンの動態", 日本薬理学杂隹誌, Vol.127, No.4, pp.267-272(2006) 